\section{A földhasználat alakulása az ezredfordulón - egy felmérés eredményei*}

\section{Posta László}

Debreceni Egyetem Agrártudományi Centrum, Agrárgazdasági és Vidékfejlesztési Intézet, Vállalatgazdaságtani Tanszék, Debrecen

\section{ÖSSZEFOGLALÁS}

A földtulajdonlás, -használat vonatkozásában 2000-re a kárpótlás utáni állapothoz képest nem sok változás történt. A tulajdonlás zömmel most is azokhoz kapcsolódik, akik nem akarják használni tulajdonukat, ezért a földhasználat általános jogcime az esetleges saját tulajdonú földet kiegészitendö - ma is a bérlet. A földbérlö gazdaságok nagyon eltérö viszonyok között gazdálkodnak, bár törekednek arra, hogy inkább a jobb minöségü földeket vegyék bérbe. A vizsgált gazdaságok zömmel növelnék a rendelkezésükre álló földterületet vásárlás illetve bérlet útján. A vásárlást a még mindig várható további árnövekedés miatt jó befektetésként értékelik, azonban tökehiány miatt föleg a bérlet jöhet szóba területnövelési módként. A földet bérlö gazdaságok nagyon sok tulajdonossal állnak kapcsolatban, s az általuk használt termöföld igen elaprózódott, nagyon sok tagban található. A szerzödések nagy része irásos megállapodás, azonban még mindig magas a szóbeli szerzödések aránya, melyek leszoritása célként fogalmazható meg. Jellemzö a középtávú bérleti szerzödések dominanciája, ami mindkét fél érdekének megfelel, ugyanakkor még mindig magas a rövid távra szóló megállapodások részaránya is. A bérleti díj átlagos alakulása a vizsgált gazdaságok vonatkozásában kiegyensúlyozottnak tekinthetö, 16.000 Ft/ha körüli értéken alakul. Többnyire a bérlök azonos bérleti dijat fizetnek a tulajdonosoknak, azonban bizonyos esetekben elöfordul a differenciálás. A szerzödések többségében fix összegü bérleti dijat fizet a bérlö, emellett elöfordul, hogy a bérleti dijat a termés, illetve az értékesitési ár változásától teszik függővé a felek. A bérleti dij átlagosan 16\%-át teszi ki a termelés költségeinek a vizsgált gazdaságokban, amelyek a bérbe veendö földek kiválasztásakor zömmel igyekeznek a földminöséget és a terület nagyságot figyelembe venni. Néhány esetben a jobb minöségü föld egységéért nagyobb dijat hajlandók fizetni a gazdaságok, de ez nem általános tendencia, inkább igaz az, hogy egyforma a jobb és a rosszabb minöségü földek egységére - egy aranykoronára - fizetett fajlagos bérleti díj alakulása. A földtulajdonosok igazából nem szólhatnak bele földjük használatába a bérleti idö alatt, és összességében jellemzö a szerzödésekre az, hogy lényeges kérdéseket nem, vagy nem eléggé körültekintöen szabályoznak, igy a szerzödések fejlesztése szükséges a jövöben.

\section{SUMMARY}

There were no significant changes in land ownership and use in 2000, compared to the period following the compensation process. Land is mainly owned by people who do not want to use their property, so they generally turn to renting it out to others. Although farming on rented land is performed under various conditions, farms try to rent the lands of better quality. In general, examined farms would like to increase their size by tenancy or land purchase. Buying land is a good investment, considering the price increase in the future, but because of the lack of capital, tenancy remains the main form of territory increase.
Farms which rent land are in connection with a lot of owners, the land within their use is frittered away, it is in a lot of parts. Most rental contracts are written, but the ratio of oral contracts is still quite high. To reduce this ratio is one future aim. One more characteristic of the rental contracts is the dominance of a medium length period - which is acceptable for both the owner and user, but the ratio of short time contracts is still high. Land rent, on average for the examined farms, is quite balanced, it is on the level of about 16.000 HUF/hectare.

The land users mainly pay the same land rent to the owners, but in some cases, there are exceptions. Generally, land rent is a fix cost, but sometimes this cost depends on the level of the yield or the change of product price. Land rent, on average, is $16 \%$ within the production costs on the examined farms, which try to choose better and larger lands for rent. Sometimes, farmers can pay higher land rent for the unit of better land, but this is not a general tendency. It is mainly true that they pay the same land rent for the unit, regardless of land quality. Land owners can not interfere in the use of their land within the rental period, and also is a main characteristic of contracts that important particulars are not spelled out sufficiently by the partners. It follows that their content has to be improved in the future.

\section{BEVEZETÉS}

Az 1990-es évek elején lezajlott kárpótlási folyamat eredményeként Magyarországon elvált egymástól a termőföld tulajdonlása és használata. Rendkívül sok, apró földtulajdon alakult ki, aminek következtében az átlagos birtokméret 2-5 ha-ra, a tulajdonosok száma pedig 2 millióra volt tehető. Az említett méret nem teszi lehetővé az élethivatásszerü gazdálkodást, mivel nem biztosít sem elegendő munkát, sem megfelelő megélhetést a vállalkozó és családja számára. Ehhez ugyanis - óvatos becslések szerint is - legalább 50-70 ha-os területre van szükség, ha feltételezzük, hogy a gazdálkodó szántóföldi növénytermesztést kíván végezni (Pfau, 1995). Annak tehát aki úgy döntött, hogy mezőgazdasági termelést végez, meglévő földje mellé továbbiakat kellett vásárolni, vagy bérelni. Ez a két lehetőség is csak a magántulajdoni alapon müködő egyéni gazdálkodóknak volt adott, hiszen a gazdasági társaságok, szövetkezetek számára a törvény csak az utóbbi - a bérleti - lehetőséget kínálta fel, mivel ők földet nem vásárolhattak a Földtörvény értelmében. (1994. évi LV. tv.) A kárpótlást követően így meglehetősen zilált tulajdoni - használati viszonyok alakultak ki, a földhasználatban általánossá vált a bérlet, $\mathrm{s}$ ezen belül is többféle módozat alakult ki. Jellemző volt erre az időszakra, hogy gyakran ad hoc jelleggel köttettek a bérleti szerződések, a bérleti kultúra nagyon kialakulatlan volt, nem úgy mint egyes 
nyugati országokban, ahol ennek több száz éves múltja, kultúrája figyelhető meg, ami a földtulajdonos és a bérlő számára egyaránt megbízható rendszert nyújt (Szücs, 1998). Az Európai Unió országaiban különösen a bérlő biztonságának megteremtését helyezik előtérbe, ami a gazdálkodás hosszabb távú megalapozását szolgálja (Pálovicsné, 1997). Ezzel szemben az Egyesült Államokban a földtulajdonos és a bérlő jelentős szabadságot élvez a szerződések megkötésekor. A bérleti megállapodások között gyakoriak az egy évesek, ami viszont éppen nem a bérlő érdekeit védi. Ugyanígy nem kedvez a bérlőnek, hogy földeladás esetén nincs elővételi joga, hacsak korábban a szerződés ezt ki nem kötötte (Szabó, 1997). A magyar földtulajdoni és használati rendszer EUkonform korszerüsítése összehangolt stratégiát kíván, aminek része kell legyen az is, hogy milyen üzemméretü gazdaságokat, milyen feltételek mellett illet meg támogatás az állam részéről pl. földvásárlás esetén (Tanka, 1997).

E kutatást megelőzően - 1997-ben - a közvetlenül a kárpótlás utáni időszakra vonatkozó földhasználat alakulását, jellemzőit vizsgáltuk, így akkor egyfajta elözetes vizsgálatot végeztünk, melynek eredményeit most összevetve e kutatás eredményeivel a változásra, fejlődésre vonatkozóan szeretnénk következtetéseket levonni. Természetesen nem minden részletében azonos a két vizsgálat, azonban a változások tendenciáinak megállapítása így is lehetséges (Posta, 1997).

A jelenlegi kutatás - 3 évre vonatkozóan, 2000. évtől kezdődően - konkrétan azt vizsgálja, hogy a kárpótlás után hogyan alakul a földhasználat, letisztultabb képet mutat-e ma a bérleti gazdálkodás, illetve mi jellemző a jelenlegi földhasználatra. A kutatás során különböző vállalkozási formában működő gazdaságok földhasználati adatai kerültek vizsgálat alá. A különböző vállalkozási forma mellett a gazdaságok által használt földméret is igen eltérő képet mutat, ami nem véletlen, hiszen nem egyfajta gazdaságtípusra jellemző méreten akartuk vizsgálni a földhasználat alakulását, hanem a sokszínüséget kívántuk bemutatni, $\mathrm{s}$ az alapján bizonyos tendenciákat, jellemzőket rögzíteni.

A 2000. évi földhasználatra vonatkozóan 25 gazdaság adatait mértük fel, közülük $4 \mathrm{Kft}$., 7 szövetkezet, 13 egyéni vállalkozás, illetve őstermelö, míg $1 \mathrm{Rt}$. formában müködik. Jellemző volt tehát a magángazdák megkeresése már csak azért is, hogy kiderüljön, hogy jelenleg számukra milyenek a gazdálkodási feltételek, rendelkeznek-e elég földdel ahhoz, hogy gazdaságukat kiteljesítsék. Ugyanakkor arra is törekedtünk, hogy a felmérésbe nagyobb több száz, esetenként több ezer ha-on müködő gazdaságokat is bevonjunk, hiszen még mindig ök tekinthetők a legfontosabb földhasználóknak a használt földek nagyságát figyelembe véve. Helyileg a felmért gazdaságok zöme Hajdú-Bihar megyei székhelyü, ugyanakkor távolabbi gazdaságokat is bevontunk a felmérésbe. Így származnak adatok Fábiánsebestyén, Nagymágocs, Szentes térségéböl is. A kutatás kiterjesztésének szintén az volt a célja, hogy ne csak egy régió földhasználati viszonyait mérjük fel, hanem lehetőség szerint terjesszük ki azt az ország távolabbi részeire is, hogy általánosabb tendenciákat, jellemzőket fogalmazhassunk meg.

(A kutatás kezdetén a jelzett 25-nél jóval több gazdaság megkeresésére került sor, azonban a gazdaságok egy része bizalmatlanság, illetve személyes ismeretség hiánya miatt elzárkózott az adatszolgáltatástól. Sajnos ez a negatív tendencia egyre inkább megfigyelhető a rendszerváltás után, ugyanis a gazdálkodók bizalmatlanok, nem szívesen szolgáltatnak ki semmiféle adatot tevékenységükre vonatkozóan. Természetesen ez nem általánosítható, azonban gyakran a kutatást erősen hátráltató tényezőként jelenik meg.)

1. Vizsgálatunk első részében a gazdaságok által használt termőföld nagysága, mérete felől tudakozódtunk. Az előzetes várakozásnak megfelelően igen heterogén válaszokat kaptunk, mivel 15 és 4.286 ha között volt a felmért gazdaságok által használt terület, átlagosan a 25 gazdaságra vonatkozóan pedig 733 ha körül alakult a gazdaságok területe. Természetesen az, hogy egy adott vállalkozás mekkora méreten gazdálkodik, nagyon sok tényező függvénye, így befolyásolja a vállalkozás tőkeereje, eszközellátottsága, tevékenysége, a régióban található földek minősége, kereslete-kínálata stb. A felmérés alapján elmondható, hogy a családi gazdaságok - melyek kevésbé tőkeerősek és tevékenységi profiljuk sem olyan széleskörü, mint a szövetkezet, Kft., Rt. formában működőké - inkább a tízes nagyságrendü mérettől a néhány 100 ha-os méretig voltak fellelhetőek (legnagyobb méretet e csoportban a 300 ha jelentette), míg a többi gazdaságra a 100-as, 1000es területi nagyságrend volt jellemző. (1.000 ha felett a megkérdezettek közül 3 szövetkezet, $1 \mathrm{Kft}$. és $1 \mathrm{Rt}$. gazdálkodik.) Ez alapján megállapíthatjuk, hogy jelenleg nagyon heterogén a mezőgazdasági vállalkozások méret szerinti alakulása, a rendszerváltás utáni gazdálkodást méret tekintetében a sokszínüség jellemzi. A néhány 10 hektáros gazdaságok mellett megtalálhatók a több 1.000 ha-os gazdaságok is, így a koncentráció, valamint a nagyobb méretre való törekvés is fellelhetö.

A vizsgált gazdaságok általában arra törekedtek, hogy minél jobb minőségü földeken végezzenek gazdálkodást, ennek megfelelően az általuk használt földminőség - az összes mezőgazdasági terület vonatkozásában - az átlagos 17 AK/ha-tól jobbnak mondható, mivel $21 \mathrm{AK} /$ ha-os volt. Természetesen itt is jócskán találhatók eltérések, hiszen 14-35 AK/ha között változott a gazdaságok által használt termőföld átlagos minőségének értéke. Ez azt jelenti, hogy sok helyen hiába törekedtek jobb földet bérelni, azonban a helyi adottságok miatt - gyenge földek dominanciája abban a körzetben -, vagy a termelési kényszer okán - azon kell gazdálkodni, amit felajánlanak a tulajdonosok, mivel más nincs - olyan földet is kénytelenek voltak használni a gazdálkodók, amelyek nem kiemelkedő minőségüek. 
Ha mind a használt föld méretét, mind a minőségét csak a szántóra vonatkozóan vizsgáljuk, akkor kiderül, hogy az átlagos szántó terület nagysága 646 ha - 15-3.680 ha között -, az átlagos minőség pedig $23 \mathrm{AK} / \mathrm{ha}$ - 16-35 AK/ha között -, ami egyrészt azt mutatja, hogy a gazdaságok elsődlegesen szántón folytatnak gazdálkodást, s csak kiegészítő jelleggel bérelnek gyepet is, másrészt a használt szántóra vonatkozóan még inkább szem előtt próbálták tartani a jó minőséget. Ez érthető is, hiszen - föleg a jelenlegi közgazdasági körülmények között - csak a jobb minőségü területeken éri meg gazdálkodni, de ha általánosságban fogalmazunk, akkor is igaz az, hogy mindig a jobb minőségü földeken érvényesülnek jobban a ráfordítások, a gyengébb minőségen csak alacsony ráfordítási szint mellett lehetséges hatékonyan gazdálkodni.

Akkor, ha a földhasználat jogcímét vizsgáljuk a felmért gazdaságokban, megállapítható, hogy a 25 gazdaságból 15 rendelkezik saját földdel, bérelt területe 22 gazdaságnak van, míg 12 esetben saját és bérelt földhasználattal is találkoztunk. Csak saját földön - 3 gazdaság - föleg a családi gazdaságok végeznek termelést, amelyek kisebb termékvolument állítanak elö, ezért nem tartották szükségesnek a meglévő termőföldterület növelését, illetve amelyeknek nem volt lehetőségük további területet bérelni. Ezzel szemben a saját és bérelt földön gazdálkodók igyekeztek gazdaságuk méretét növelni, részben mert nagyobb volumenben kívántak termékeket előállítani, részben mert lehetőségük is volt rá, hogy földet béreljenek, illetve esetlegesen ökonómiai megfontolásokat is szem előtt tartva - pl. jobb gépkihasználás - növelték gazdaságuk méretét. Csak bérelt földön gazdálkodik 10 gazdaság zömmel szövetkezetek, melyeknek nem volt lehetőségük a vásárlásra -, illetve amelyek tőkekímélés miatt nem akartak saját földet vásárolni, így inkább a bérleti gazdálkodást választották. A legnagyobb saját földtulajdon 291 ha, míg a legnagyobb bérelt terület 4.268 ha volt. 4 gazdaság esetében találkoztunk „egyéb” megjelölésű földhasználattal, ami tehát nem saját, illetve bérelt területet jelentett, hanem zömmel ún. maradványföldek voltak, ami azt jelenti, hogy különböző egyéb jogcímen maradtak a gazdaságok kezelésében, használatában.

A konkrét jelenlegi állapot felmérése után, a következőkben afelől érdeklödtünk, hogy ha módjukban állna, növelnék-e az általuk használt termőföld méretét a gazdaságok. Erre vonatkozóan 24 gazdaság - 96\% - igenlő választ adott, ami jelzi egyrészt a gazdálkodók szeretetét, ragaszkodását a földhöz, másrészt azt is, hogy még korántsem sikerült kiteljesíteni gazdálkodásukat, további lehetőségekre várnak a földszerzést, illetve a gazdaság bővítését illetően. A különböző területnövelési változatok közül legtöbben (14) a bérletet jelölték meg szóbajöhető alternatívaként, ugyanakkor 13 esetben egy válaszadó többféle lehetőséget is megjelölhetett - a vásárlás is megjelent területnövelési módként. 2 esetben egyéb úton szerettek volna több földhöz jutni - öröklés -, míg 1 szövetkezet vezetője válaszolt úgy, hogy nem akarja tovább növelni az általa használt -3.450 ha - területet. E méret esetében ez teljesen indokolt döntésnek tünik, hiszen ekkora területen már nagyüzemi gazdálkodás végezhető, a méretgazdaságosság kritériumát itt már sikerült megoldani. Vélhetően ők a rendszerváltás előtt sem gazdálkodtak ettől sokkal nagyobb területen, így már korábban berendezkedtek egy általuk irányíthatónak vélt gazdálkodásra, amit nem kívánnak tovább bővíteni. Ugyanakkor a többi 24 gazdaság válasza igen egyértelmű, földszerzési törekvéseik révén kívánják biztosítani hosszú távon gazdálkodásukat. Az, hogy ezt eddig nem tették meg, illetve hogy még további területnövelést szeretnének elérni az eddigiek mellé, azt jelzi, hogy nem elég tőkeerösek ahhoz, hogy ezt kivitelezhetnék (illetve a hatályos földtörvény nem teszi azt számukra lehetővé) (1. ábra).

1 ábra: A területnövelést tervezők aránya (\%)

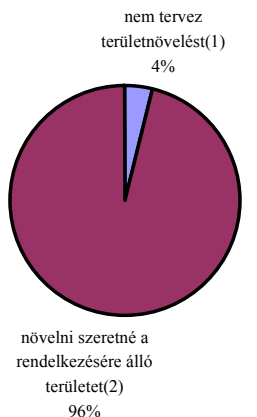

Figure 1: Ratio of farmers, who are planning farm size increase

do not plan farm size increase(1), plan farm size increase(2)

A földvásárláshoz kapcsolódóan tudakozódtunk a gazdaságok körzetében jellemző földárak iránt is. Ez esetben is igen árnyalt képet kaptunk, hiszen - mint az várható volt - igen nagy szórást mutattak a termőföldárak. Az aranykoronánkénti földár alakulást 3.000-18.000 Ft közötti értékek szemléltették átlagosan mintegy $12.000 \mathrm{Ft}$-, attól függően, hogy milyen földminőség jellemzi a gazdaságokat. Ennek megfelelően a hektáronkénti földár is nagy differenciákat mutat, hiszen 63.000 és $500.000 \mathrm{Ft} / \mathrm{ha}$ os áron lehet földet vásárolni a felmért régiókban. (Az átlagos érték 280.000 Ft/ha volt.)

Természetesen a földár alakulását a mindenkori keresleti-kínálati viszonyok mellett az adott ökológiai-ökonómiai tényezők is befolyásolják, ugyanakkor nem hagyható szó nélkül az sem, hogy ezek az árak még mindig igen alacsonyak az Európai Unió viszonylatában, az ottani árakhoz képest. Főleg igaz ez a $63.000 \mathrm{Ft} /$ ha-os föld esetében, ami bár gyenge földminőségnél áll fenn, ezzel együtt igen alacsony árnak számít. Az $500.000 \mathrm{Ft} / \mathrm{ha}$-os földár már közelít a nyugat-európai árszinthez, azonban itt is vannak még távlati lehetőségek az áremelkedés viszonylatában. (Természetesen azt is figyelembe kell venni, hogy a felmért gazdaságok az ország keleti felében találhatók, így a földárak is a keleten tapasztalható viszonyokat reprezentálják. NyugatMagyarországon ettől jóval nagyobb értékek lettek 
volna regisztrálhatók, azonban sajnos a kutatás szükös anyagi keretei nem tették lehetővé nyugatmagyarországi gazdaságok kutatásba történő bevonását.) Összességében tehát a földárak alacsonynak minősíthetők a vizsgált régióban, azonban megjegyzendő, hogy a gazdaságok számára még ezek az alacsony árak sem tünnek elérhetőnek, nem engedhetik meg maguknak a földvásárlást, mivel erőforrásaikat egyéb termelési eszközök vásárlására kell fordítaniuk.

Anyagi potenciáljukat feltérképezendő a kutatás következő kérdése arra irányult, hogy milyen árat tartanának elfogadhatónak akkor, ha mégis földvásárlást terveznének. Ez esetben 3.000-16.000 Ft/AK közötti értékeket kaptunk, míg 1 hektárra vonatkozóan 63.000-tôl 400.000-ig terjedtek az elfogadhatónak tartott értékek. (Az átlagos érték $11.000 \mathrm{Ft} / \mathrm{AK}$, illetve $253.000 \mathrm{Ft} / \mathrm{ha}$ volt.) Mint látható, ezek nem esnek távol a jelenlegi valós áraktól, ami azt jelzi, hogy a gazdák nem elsősorban azért nem vásárolnak, mert magasnak tartják az árakat, hanem azért, mert nem áll rendelkezésükre a szükséges tőke mennyisége. A vásárlást tehát fontolgatják, szeretnék növelni földtulajdonukat, azonban jelenlegi problémáik miatt egyelőre inkább elhalasztják a termőföld vételt. Érezhető, hogy nem szívesen odázzák el az ez irányú döntéseket, mivel tudják, hogy az idő ez esetben nem nekik dolgozik, hiszen az árak emelkedése figyelhető meg mindegyik vizsgált gazdaság körzetében. Addig kellene tehát a vásárlást lebonyolítani, ameddig még elfogadható szintű a földár, mert a későbbiekben - az EUcsatlakozás után - a magas földárak beállásakor már esélyük sem marad a tulajdonnövelésre. Ezt támasztják alá a várható jövőbeni árra vonatkozó válaszok is. A gazdák tudatában vannak annak, hogy a jelenlegi árviszonyok még korántsem érték el az európai árszintet, $\mathrm{s}$ várakozásuk szerint 1 ha szántóföld ára a jövőben 300.000 és 2.000.000 Ft között fog alakulni. (Átlagot számítva a válaszokból, $700.000 \mathrm{Ft} / \mathrm{ha}$ körüli értéket kapunk.) Valószínüsíthető, hogy várakozásaik helytállóak, s a magyar földár a jelzett árszint körül fog alakulni.

2. A további kérdések a bérleti gazdálkodásra irányultak, s elöször arra vonatkoztak, hogy a földet bérlő gazdaságok kiktől vettek bérbe termőföldet. Jellemző, hogy a szövetkezetek elsősorban tagjaiktól béreltek földet, de itt is nagy különbségek mutatkoztak a gazdaságok között. Így a tagoktól bérelt földterület 30 és 2.415 ha között változott, s a vizsgált 25 gazdaságból 7 bérelt földet tagjaitól is, átlagosan 932 ha-os nagyságban. Ettől jóval lényegesebb a kívülállóktól, illetve az egyéb felajánlóktól történő bérletek volumene, kívülállóktól bérel 12 gazdaság átlagosan 659 ha-t - a szórás igen nagy, 12 és 3.038 ha közötti a legkisebb és a legnagyobb érték -, míg egyéb felajánlóktól is bérel 13 gazdaság, átlagosan 240 ha-t -7 és 1.333 ha közötti legkisebb és legnagyobb értékkel. E vonatkozásban is nagyon heterogén tehát a kép. A vizsgált 25 gazdaságból 22-ben bérelnek földet, a szövetkezetek főleg tagjaiktól, de azon felül bárkitől, aki felajánlja, s a többi vállalkozási formánál szintén ez utóbbi a meghatározó.

Jól jellemzi a bérleti viszonyokat az is, hogy a bérelt földnek hány tulajdonosa van. Előfordul egyéni vállalkozó esetében -, hogy csak 1 tulajdonossal áll bérleti szerződésben a gazda, azonban nem ez a jellemző, mivel átlagosan 232 főtől bérelnek földterületet a gazdaságok. (Legkevesebb az előbb említett 1 tulajdonos, míg legnagyobb értéket mutat - Rt. esetében - az 1465 (!) tulajdonossal szerződésben álló gazdaság példája.) Általános vonás tehát az, hogy a nagy területet bérlő gazdaságok igen sok tulajdonossal állnak kapcsolatban. Nem ritkán külön szervezeti egység foglalkozik a bérleti szerződésekkel ezekben a gazdaságokban! A földtulajdonosok nagy számával van összefüggésben a gazdaságokban található földtagok száma, ami - a várakozásnak megfelelően - szintén igen magas. Így arra a kérdésre, hogy a bérelt termőföld hány darabban található, 1 és 150 (!) közötti értékek adódtak - az átlagos érték 22 volt. Rendkívül széttagoltak tehát a gazdaságok által használt területek, ami a munkaszervezést, a gépek szállítását, áthelyezését igen nehézzé teszi. Mindenképp indokolt lenne a földkoncentrációra való törekvés ami a gazdaságok részéről érezhetően meg is van -, azonban nem igazán tudnak mit tenni ez ügyben, a tulajdonosokkal való egyeztetés gyakorlatilag megoldhatatlan problémát jelent ott, ahol több száz földtulajdonos van.

A bérleti szerződések megkötésének módja szintén vizsgálat részét képezte. E vonatkozásban megállapítható, hogy a gazdaságok 78\%-ban írásban, míg 22\%-ban szóban kötik meg a bérleti megállapodásokat. A korábbi vizsgálatok alapján úgy tünik, hogy az írásbeli szerződések terjedése figyelhető meg - korábban több volt a szóbeli szerződések részaránya -, a szóbeli megállapodások visszavonulóban vannak, bár százalékos arányuk még mindig relatíve magasnak tünik. 17 gazdaságban 100\%-os az írásban kötött szerződések aránya, 2 gazdaságban 85 , illetve $88 \%$ ez az arány, míg $100 \%$ ig szóban kötik a bérleti szerződéseket 5 gazdaságban. Ez utóbbi főleg a magánvállalkozókra jellemző, akik néhány tulajdonostól bérelnek földet, míg a nagyobb területeken gazdálkodók egyértelműen az írásban kötött szerződéseket preferálják, saját, illetve a földtulajdonosok biztonságát is szem előtt tartva. Érdekesség, hogy éppen 2 szövetkezet esetében fordult az elö, hogy keverten jelentek meg írásos és szóbeli megállapodások, azonban itt is az írásbeliek dominanciája volt megfigyelhető (85, illetve $88 \%$ ban, mint az már korábban említésre került). Célszerü lenne erre vonatkozóan 100\%-ig az írásbeli szerződések gyakorlatát megvalósítani, hiszen mindkét fél számára előnyösebb, ha írásban rögzítettek a bérleti feltételek (2. ábra). 
2. ábra: A bérleti szerződések jellege (\%)

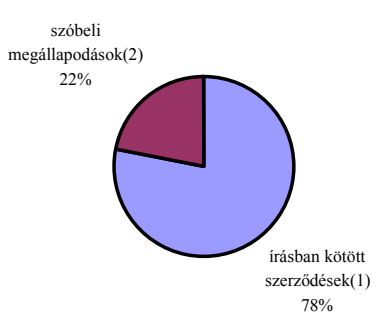

Figure 2: Character of rental contracts written contracts(1), oral contracts(2)

3. A bérleti időszak kiterjedésére, idejére vonatkozóan is vizsgálódást folytattunk. Ekkor arra voltunk kíváncsiak, hogy a bérlők milyen mértékben tudják biztosítani termelésük folyamatosságát, illetve hogy a földtulajdonosok hány évre hajlandók lemondani tulajdonuk használati jogáról. Megállapítható, hogy a megkötött bérleti szerződések mintegy $1 / 5$-e $(21,3 \%) 1$ évre, $15,4 \%$-a 3 évre, $57,2 \%$-a 5 évre, míg 6,1\%-a 5 évnél hosszabb időszakra szólt. A vállalkozások próbálták tehát legalább középtávra - 5 év - biztosítani a gazdálkodás folyamatosságát, azonban ez az 1 évre szóló szerződések esetében nem sikerült. Vélhetően e földek tulajdonosai voltak a legbizalmatlanabbak a bérlőkkel szemben, s nem akarták, hogy tulajdonuk hosszú távra kikerüljön döntésük alól. Az is elképzelhető, hogy ezek a tulajdonosok a termőföld értékesítését tervezik rövid távon, $\mathrm{s}$ ezért nem akarnak hosszú távra szóló bérleti szerződést kötni. A bérlők számára biztatóbb a helyzet a 3 éves szerződések esetében, amik már valamivel hosszabb távra szóló tervezést tesznek lehetővé. Az 5 éves szerződések magas részaránya pedig azt jelzi, hogy a földtulajdonosok összességében nem annyira bizalmatlanok, mint a kárpótlási folyamat után közvetlenül, amikor az volt a meghatározó gyakorlat, hogy csak 1 évre szóltak a szerződések. Ezzel együtt az 5 éven túli szerződések alacsony aránya jelzi azt, hogy azért a földtulajdonosok zöme nem akarja túl hosszú távra más használatába adni földjét, vagy ha akarja is, azt majd újabb szerződés megkötésével fogja elérni. Ezáltal a gazdálkodók továbbra is kiszolgáltatottak a tulajdonos akaratának, egyfajta mesterséges hiánykeltés áldozatává válnak a földhasználók. A földtulajdonos hiánykeltő magatartása gondoskodik egyúttal arról is, hogy permanens földkereslet legyen érzékelhető a földhasználók között, s ez által emelkedjenek a felkínált bérleti díjak, még esetlegesen akkor is, ha a gazdálkodás jövedelmezőségi pozíciója azt egyébként nem teszi lehetővé. A földhasználó így saját tökejáradéka rovására is - kénytelen emelni a bérleti díjat, ha nem akarja, hogy „kihúzzák alóla” gazdálkodása színterét, a termőföldet. A gazdálkodási kényszer, a meglévő eszközök kihasználásának igénye, szintén ezt a folyamatot erősíti. Ebből a szempontból tehát, bár csökkent a termelök kiszolgáltatottsága, de összességében a tény nem változott, a földhasználók továbbra is ki vannak téve a földtulajdonosok növekvő földjáradék igényéből fakadó bizonytalanságnak. Ugyanakkor a földtulajdonos minél nagyobb és biztosabb bérleti díjra, földjáradékra való törekvése is érthető, hiszen nem várható el tőle sem, hogy saját érdekét mellőzve, csak a földhasználó javát igyekezzen szem elött tartani. Összességében megállapítható, hogy a középtávra való szerződésekkel mindkét fél érdeke kielégítést nyerhet, ez az idöszak sem nem túl hosszú, sem nem túl rövid ahhoz, hogy ne tervezhetnének vele megfelelően a felek. Ezért az 5 évre szóló szerződések kötése mindkét fél számára célszerünek, illetve elfogadhatónak tűnő megoldás (3. ábra).

3. ábra: A bérleti időszak hossza

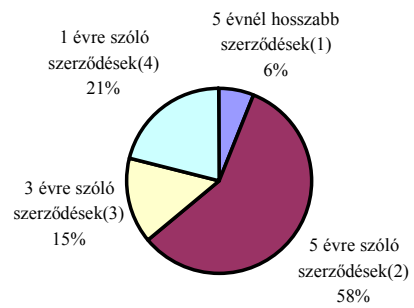

Figure 3: Time period of rental contracts

contracts for more than 5 years(1), contracts for 5 years(2), contracts for 3 years(3), contracts for 1 year(4)

4. A bérleti szerződés egyik legfontosabb pontja magának a bérleti díj nagyságának az alakulása, így természetesen erre is kitért adatgyüjtő munkánk. Mivel a bérleti díj megállapítása többféle módon is történhet, ezért ennek megfelelően a kérdésfeltevésünk is különbözött, attól függően, hogy a gazdaságokban hogyan állapítják meg - mire vonatkozóan - a fizetendő díj nagyságát. A legegyszerübb módja a bérleti díj megállapításának az, ha a területegységre - hektárra - fizetendő díj nagyságát rögzíti a szerződés. Ekkor ez az érték fixnek tekinthető, függetlenül a földminőségtől, illetve a gazdálkodás, valamint a közgazdasági környezet - árak, költségek - alakulásától. Azokban a gazdaságokban, ahol így határozták meg a bérleti díjat, $16.400 \mathrm{Ft} / \mathrm{ha}$-os átlagos értéket kaptunk, meglehetősen nagy differenciákkal, ugyanis 10.000 és $20.000 \mathrm{Ft} /$ ha között változtak az értékek. Ha a földminőségre vonatkozóan 1 aranykoronára tartalmazta a szerződés a bérleti díjat, akkor is nagyon változatos képet kaptunk, mivel ez esetben az átlagos érték $773 \mathrm{Ft} / \mathrm{AK}$ értéket mutatott, 400 és $1.000 \mathrm{Ft} / \mathrm{AK}$ közötti váltakozással. Akkor pedig, ha a bérleti szerződésekben leggyakoribb - a földminőségre vonatkozóan gabonában (búzában) adták meg a díjat, átlagosan $28 \mathrm{~kg}$ búza/AK értéket kaptunk, 18 és 37,5 kg/AK közötti értékekkel. A bérleti díjakban tehát mindhárom esetben igen nagy szórás volt tapasztalható régióktól, földminőségtől és egyéb tényezőktől függően, ami mutatja a bérleti gazdálkodás korántsem kiegyensúlyozott viszonyait. 
E vonatkozásban is igaz az, hogy a gazdálkodás sikerét, az elérhető jövedelem nagyságát elsősorban a földminőség határozza meg, s ez differenciálja a fizethető bérleti díj alakulását is. A jobb földminőségen gazdálkodók nagyobb jövedelmet, jövedelmezőséget képesek elérni, s ennek megfelelöen bérleti díjat is többet képesek fizetni, mint azok, akik szerény minőségü földet bérelnek. Ugyanakkor a földtulajdonosok is tisztában vannak a földminőség elsődleges jövedelembefolyásoló voltával, így azok, akik jobb földdel rendelkeznek, csak jóval nagyobb bérleti díjért cserébe hajlandók földjüket bérbe adni, mint azok, akik alacsony aranykoronaértékü termőföldet birtokolnak. A problémát viszont sokszor az okozza, hogy az aranykoronaérték nem tájékoztat pontosan a földek minősége közötti különbségről, csak hozzávetőleges értéket tükröz. Ezzel együtt az esetek többségében mind a bérlö, mind a földtulajdonos ismeri az adott terület jellemzőit, $\mathrm{s}$ ez alapján kerül kialakításra a bérleti díj a tulajdonos és a bérlő elvárásai alapján.

Ha összevetjük a háromféle bérleti díj meghatározásból származó átlagos eltéréseket, a következő megállapítást tehetjük: tulajdonképpen az átlagos bérleti díj tekintetében nagyon kiegyensúlyozott a kép, ugyanis a 3 átlagos érték $16.400 \mathrm{Ft} / \mathrm{ha}, 773 \mathrm{Ft} / \mathrm{AK}, 28 \mathrm{~kg}$ búza/AK - nagyon közel áll egymáshoz. Figyelembe véve a 25 gazdaság által használt termőföld átlagos minőségét, ami 21 AK/ha, valamint a 2000. évre jellemző átlagos búza értékesítési árat, ami $28.000 \mathrm{Ft} / \mathrm{t}$ volt, a 3 bérleti díj alakulása $\mathrm{Ft} / \mathrm{ha}$ értékre vonatkoztatva a következő: $16.400 \mathrm{Ft} / \mathrm{ha} ; 16.233 \mathrm{Ft} / \mathrm{ha} ; 16.464 \mathrm{Ft} / \mathrm{ha}$. Gyakorlatilag tehát homogénnek tekinthetök az átlagos bérleti díjak, értékük 16.200-16.500 Ft/ha között változik. (Valamivel alacsonyabb akkor, ha a Ft értéket 1 aranykoronára vonatkoztatják, valamivel magasabb akkor, ha a fizetendő gabona értékét viszonyítják a földminőség egységére.) Nem véletlen az, hogy a gyakorlatban a legsürübben ez utóbbi gabona kg-ban történő bérleti díj meghatározás formával találkozhatunk. Ez által ugyanis kivédhető az árváltozásból adódó relatív bérleti díj csökkenés, ugyanakkor a bérlő számára is előnyös lehet, ha az értékesítési kockázatot megoszthatja a tulajdonossal. Ha növekszik az ár, az kedvező a bérlő számára, és a bérleti díj is emelkedik, viszont ha csökken a termék értékesítési ára, akkor az árcsökkenés nemcsak a gazdálkodót érinti hátrányosan, hanem a bérleti díjon keresztül a föld tulajdonosát is.

A 22 földet bérlő gazdaságból 14-ben minden földtulajdonosnak azonos díjat fizetnek a termőföldért, 8-ban azonban differenciák vannak a fizetendő díj alakulásában. Azok, akik azonos bérleti díjat fizetnek, nem tesznek különbséget semmilyen vonatkozásban a földtulajdonosok között, míg a többiek esetében ez valami miatt fellelhetö. Általában 2 oka van annak, ha a gazdaságok differenciálnak: egyik esetben a szövetkezeteknél fordul az elő nagyobb számban, hogy tagjaiknak nagyobb bérleti díjat hajlandók fizetni, ezzel is egyfajta gesztust gyakorolva a tagság irányába; másik esetben - fóként az egyéni vállalkozók körében - az figyelhető meg, hogy csak néhány tulajdonostól bérelnek földet, $\mathrm{s}$ ekkor a rokoni kapcsolatokat előnyben részesítve szoktak többet fizetni, míg a többiek esetében alacsonyabb bérleti díjat ajánlanak fel a termőföld használatáért. Mindkét esetben érthető mi motiválja a bérlőket, s egyben elfogadható is, ha a szövetkezet tagjai, illetve az egyéni vállalkozó rokonai számára nagyobb bérleti díjat fizet, mint egyébként. Az említetteken kívül elképzelhető még úgynevezett „bérleti felár” fizetése akkor, ha egy bizonyos területi határ fölött ajánlja fel a földtulajdonos földjét a gazdaság használatába, hiszen a nagyobb egybefüggő méret müvelési elönyöket kínál a földhasználónak, ezért érthető, hogy ezt valamilyen formában honorálja. (Gyakran ez a forma inkább negatív diszkrimináció formájában jelenik meg, ami az jelenti, hogy bizonyos méret alatti területért kevesebbet fizet a bérlő az egyébként szokásos értéknél, vagy szélsőséges esetben nem is fogadja el a bérletbe felajánlott földdarabot. Ez akkor fordulhat elö, ha földkínálati túlsúly van az adott régióban, a potenciális bérlők száma pedig erősen korlátozott. Így a monopol helyzetben lévő bérlő „,válogathat” a felajánlott lehetőségek között.)

A bérleti díj fizetésének módja szorosan kapcsolódik a bérleti díj nagyságának megállapításához. Leggyakrabban (14 alkalommal) a fix összegként való bérleti díj fizetés szerepelt az adott válaszok között, ami jelzi azt, hogy a gazdaságok által föképp használt bérleti forma a fix díjú (készpénzes) bérleti szerződés. Ez jelenti a bérleti gazdálkodás legegyszerübb módját: a bérlőnek fix költségként, a tulajdonosnak fix összegü bevételként jelentkezik a bérleti díj. Ennek a változatnak alfajaként értékelhető az a megoldás, amikor a bérlő fix termékmennyiséget kap a földhasználat fejében. Ez 3 esetben volt fellelhetö a gazdaságok bérleti rendszereiben. Előnye az, az előzővel szemben, hogy az infláció hatása kivédhető általa, illetve annak a tulajdonosnak, aki maga is foglalkozik állattartással elönyösebb, ha közvetlenül terményben (búza, kukorica) kapja meg a fix mennyiségü bérleti díjat. Mint már utaltunk rá korábban, a bérleti szerződés fejlettebb változataként fogható fel a felek közötti kockázatmegosztás, amikor termékmennyiségtől, értékesítési árszinttől függően változik a bérleti díj nagysága. Ez esetben az a gyakorlat, hogy a felek megállapodnak egy alapdíjazásban, ami attól függően változik, hogy hogyan alakul a beiktatott korrekciós tényező (hozamszint, árszint, esetleg mindkettő). Ezzel a lehetőséggel 6 gazdaságban éltek, tehát olyan szerződéseket is kötöttek, amelyek szerint a bérleti díj az említettek függvényében változik. Egy esetben találkoztunk olyan díjfizetési konstrukcióval, amikor a gazdálkodás során előállított termék (vagy annak értéke) meghatározott része, százaléka is képezhette a bérleti díjat, ami részes bérleti gazdálkodásra utalt. Ekkor fokozott kockázatmegosztásról van szó a felek között, hiszen a gazdálkodási és az értékesítési kockázatot is megosztják egymás között. Összesen 2 esetben fordult elő az, hogy egy gazdaságnál 2 bérleti díj fizetési módra is lehetőség nyílt, a többség 
azonban egyféle szerződéseket kötött a díjfizetés vonatkozásában.

5. Mint az nyilvánvaló, a termőföld magántulajdonba kerülése, $\mathrm{s}$ ezzel a bérleti gazdálkodás elterjedése azt is eredményezte, hogy a termelés költségei között egy új költséggel a bérleti díjjal is számolni kényszerülnek immár a gazdaságok. A bérleti díj tehát a gazdálkodás költségei között - az egyéb költségek sorában található, ami azt eredményezi, hogy a gazdálkodás jövedelmi viszonyai tovább romlottak (változatlan értékesítési árat feltételezve). Arra, hogy a költségek között hány százalékkal szerepel a bérleti díj, tehát hogy milyen a bérleti díj részaránya az összes költségen belül, természetesen ismét nagyon eltérő válaszokat kaptunk. Átlagosan ez az érték 16\%, azonban a szórás itt is igen nagy, hiszen 7 és $30 \%$ között változtak az értékek, ami jelzi azt, hogy nem csekély költségtényezőről van szó. Ez még akkor is igaz, ha figyelembe vesszük, hogy a költségstruktúrán belüli arányt a gazdálkodás színvonala erősen befolyásolja, hiszen ha állandó költségként kezeljük a bérleti díjat, annak költségaránya egészen más lesz extenzív gazdálkodás esetén, illetve intenzív gazdálkodást feltételezve. (Magas ráfordítási színvonalú, intenzív gazdálkodás esetén ugyanaz a bérleti díj töredék arányt képvisel, mint alacsony ráfordítási szint esetén vizsgált költségstruktúrában.)

A bérletbe felajánlott földmennyiségre lehet következtetni abból, hogy a gazdaságok minden számukra felkínált termőföldet elfogadtak-e. Ugyanis vélhetően, ha egy gazdaság nem válogatta meg a bérelt földeket valamilyen szempont alapján, ez azt jelenti egyrészt, hogy nagy szüksége volt a termőföldre (keresleti piac), másrészt, hogy relatíve kevés volt a felajánlott földmennyiség, esetleg konkurencia harc folyt a régióban gazdálkodók között a földek bérleti jogáért. A felmértek közül minden földet elfogadott 4 gazdaság, a többiek azonban válogattak. Így 15 gazdaságban a földminőséghez kötötték a szerződés megkötését, és csak a jobb minőségü területekre kötöttek szerződést, míg 11 gazdaság volt, ahol a területi méret függvénye volt a szerződéskötés, így csak a nagyobb területü, adott méret feletti termőföldet vonták be a gazdálkodásba. 8 gazdaság engedhette azt meg magának, hogy mind minőségi, mind területi korlátot állítson a bérbeveendö földdel szemben, így ezek esetében igazak az előzőekben leírtak, nevezetesen, hogy ezeknél a gazdaságoknál nem kellett a konkurenciától tartani, megtehették, hogy csak a számukra legkedvezőbb adottságokkal rendelkező területeket választják ki, mivel valószínűleg egyedül ők jöttek szóba potenciális bérlőként az adott régióban. Az egy feltételt állítók náluk kevésbé, a semmilyen feltételt nem szabók pedig egyáltalán nem válogathattak. Az is valószínüsíthető, hogy a régió földminősége is erősen befolyásolta a gazdálkodók ez irányú viselkedését, hiszen jó minőség esetén vélhetően több bérlő jelentkezett, erősödött a konkurenciaharc, s így a válogatásnak kisebb esélye volt, míg a rosszabb földek esetében beszükült a „földért harcba indulók köre”, kevés gazdaság versengett a felajánlott relatíve sok földért, s ez a kevés (esetleg 1) határokat, feltételeket szabhatott saját elgondolásainak megfelelően.

Előfordult egyes esetekben, hogy a bérleti díj nagysága a földminőség egységére - 1 aranykoronára - vonatkozóan eltért akkor ha jobb, illetve ha kevésbé jó minőségű földről volt szó. Ez megfigyelhető a vizsgált gazdaságok esetében is, hiszen 15 esetben $(68 \%)$ nem különbözött a fajlagos bérleti díj alakulása, azonban 7 esetben (32\%) igen. Gyakorlatilag tehát a földet bérlő gazdaságok 1/3-a magasabb díjat állapított meg a jobb minőségü földek 1 aranykoronájára vonatkozóan, mint az alacsonyabb minőségü földek esetében, ezzel is azt elősegítendő, hogy inkább a jobb földeket vehessék bérbe, ösztönözve a tulajdonosokat is arra, hogy magasabb bérleti díjért inkább nekik ajánlják fel a termőföldet, sem mint az esetleges konkurenciának.

6. A földtulajdonosok szempontjából nagy jelentősége van annak, hogy a bérleti időtartam alatt beleszólhatnak-e és ha igen, akkor mi módon, földjük használatába. Ez azért fontos, mert ha a földtulajdonos valahogyan kontrollálni tudja földjének használatát, akkor azzal esetleg kivédheti azt, hogy a bérleti időszak során a bérlő ne a jó gazda gondosságával járjon el, vagyis hogy kizsarolja a bérbevett termőföldet. Ezt megakadályozandó, a tulajdonosnak elemi érdeke, hogy szemmel kísérhesse - s adott esetben alakíthassa - a gazdálkodás módját, legalább a tápanyaggazdálkodással összefüggésben. Ha erre nem kerül sor, akkor félö, hogy a bérlet lejártakor kizsarolt, tápanyagtartalom szempontjából erősen leromlott minőségü földet kap vissza a tulajdonos, s nyilvánvalóan e föld értéke ekkor már jóval kevesebb lesz a bérlet előtti időszakéhoz képest. Ez a veszély főleg a hosszú távú szerződések esetén áll fenn. A tulajdonosok a vizsgált földet bérlö gazdaságoknál csak mindössze 5 esetben (23\%) szólhattak bele a földhasználatba, a többinél erre nem nyílt módjuk. Így az esetek többségében a tulajdonos kiszolgáltatottá válik a bérlő döntéseivel szemben, föleg, ha a bérleti szerződésbe nincs egy olyan záradék beiktatva, ami szabályozza valamilyen módon a bérlő földhasználatát. A bérlők persze a „beleszólás” lehetőségétől igyekeznek távol tartani a földtulajdonosokat, mondván, hogy káoszhoz vezetne, ha minden döntésüket kontrollálhatná a földtulajdonos, kezdve attól, hogy a bérelt földön milyen növény termesztésével foglalkozhatnak. Ebben van igazság, nem is célszerü az ilyen jellegü döntésekbe túlzott beleszólást engedni - kivéve részes bérleti gazdálkodás esetén, amikor nem csak a termesztendő növények körét, hanem esetlegesen a felhasználásra kerülő ráfordítások szintjét is közösen határozhatják meg a felek -, azonban a föld állagmegóvására tett tulajdonosi törekvést el kell fogadni, ezért valamilyen formában rögzíteni szükséges azt, hogy a bérlő milyen állapotban köteles a földet visszaszolgáltatni a bérlet lejárta után, illetve 
hogy milyen jellegü gazdálkodást kell végeznie az állagmegóvás érdekében.

Ez utóbbi kérdés már szoros összefüggésben áll a szerződések tartalmi vonásaival, azzal, hogy általában mire terjed ki a szabályozás a szerződésekben. A kutatás során vizsgáltuk tehát a szerződéseken belül néhány fontosabb tartalmi kellék meglétét, azaz hogy az egyes esetekben megtalálhatók-e azok a gazdaságok által kötött megállapodásokban. Fontos kérdés például, hogy a szerződés tartalmazza-e pontosan a bérleti díj fizetésének időpontját. A 22 földet bérlő gazdaságból 21 szerződésében ez megtalálható volt, 1 esetben viszont - mivel az egyéni gazdálkodó rokonától bérelte a földet - nem egyértelmüsítették a fizetés időpontját. Rokontól való bérlet esetén ez esetleg elfogadható, azonban célszerünek tünik minden esetben - a félreértések elkerülése miatt - ennek rögzítése.

A bérlő által követendő gazdálkodási gyakorlat rögzítése az előbbiekben - a „,beleszólás” kapcsán leírtak miatt igen lényeges. Mint ahogy ott is láttuk, erre nem igazán terjedt ki a felek figyelme, mindössze 5 szerződés tartalmazta ezt a kelléket. Ez mindenképp fejlesztendő vonás tehát a szerződések vonatkozásában, mivel az, hogy a tulajdonosi érdekek figyelmen kívül hagyásra kerüljenek, nem lehet célja egy körültekintő és hosszú távra szóló bérleti rendszernek.

$\mathrm{Az}$ esetleges nézeteltérések tisztázásának módja már szabályozottabban jelent meg a szerződésekben, bár ez is csak 50\%-ban (11) volt fellelhető. A bérlet megújításának módja ismét kevesebb (9), felmondásának módja pedig valamivel több (13) esetben volt fellelhetô, mint a nézeteltérések tisztázásának illetékességére történő utalás. Mindegyik említett tényező esetében ugyanaz javasolható, mint a díjfizetés időpontjára, illetve a követendő gazdálkodási gyakorlatra vonatkozóan már előbb leírtak: lényeges tartalmi kellékei a szerződéseknek, tehát ne maradjanak ki azokból! (Ezért is célszerü lenne mindig írásban kötni a szerződést, mivel akkor elvileg körültekintőbbek a felek: mindkettő elolvashatja, kiegészítheti, finomíthatja a szerződést. A szóbeli szerződés jellegéből adódóan - nem tud elég körültekintő lenni, és egyébként is bármelyik fél szenvedhet később „emlékezetkihagyásban”. Írásbeli szerződésnél az aláírás tanúsítja a feltételek tudomásul vételét, nehezebb megtámadni, mint egy szóbeli megállapodást.)

Bár az előbbiekben már vizsgáltuk a tulajdonos „beleszólási” lehetőségét a gazdálkodás mikéntjébe, valamint azt is, hogy a szerződés tartalmazza-e a bérlő által követendő gazdálkodási gyakorlat szabályozását - s mindkét vonatkozásban csak 5 igenlő választ találtunk -, még egyszer rákérdeztünk ezekkel összefüggésben arra, hogy a szerződések a föld visszaadáskori állapotát szabályozzák-e. A két korábban vizsgált elemre adott válaszokkal ellentétben, e kérdésre jóval több (13) pozitív visszajelzés érkezett, ami azt jelenti, hogy bár sem a konkrét beleszólási lehetőség nem adott a tulajdonos számára, sem az nem szabályozott kellőképpen, hogy a bérlő mit csinálhat bérleményén a bérleti periódusban, azt azért mégis csak szabályozzák több szerződésben, hogy a termöföldnek milyen állapotban kell visszakerülnie a tulajdonoshoz (4. ábra).

4. ábra: A bérleti szerződések tartalma (\%)

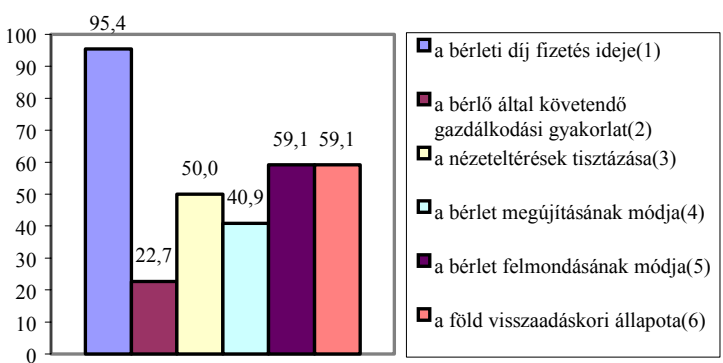

Figure 4: Content of rental contracts

timing of the pay of land rent(1), farming way of the tenant(2), resolution of misunderstandings(3), renewal of contracts(4), cancellation of contracts(5), condition of land at the time of the end of tenancy (6)

Hangsúlyozzuk, hogy a 13 igenlő válasz - ami 59\%-a a bérleti szerződéssel rendelkező gazdaságoknak - sem tekinthető elégségesnek, mert minden egyes megállapodásnak részének kellene lennie e kelléknek, de azért nem annyira negatív a kép, mint az első megítélésre annak tünt. Más kérdés az is, hogy a 13 igenlö válasz mögött pontosan mi rejlik. Valószínüsíthető, hogy a visszaadáskori állapot szabályozása is csak felszínes szabályozást jelent, s nem talajvizsgálati adatok összevetésével tárják fel, hogy pontosan mi történt tápanyaggazdálkodási szempontból a bérleti időszak alatt. Tehát nem elég önmagában csak arra ösztönözni a feleket (föleg a tulajdonost) hogy a szerződés tartalmazza a visszaadási állapotra vonatkozó megkötést is, de azt is célszerü rögzíteni, hogy a talajállapot bérleti idő előtti és utáni jellemzőit talajvizsgálati módszerekkel kell meghatározni, valamint, hogy az eltérések esetén mi a teendő. (Az is előfordulhat, hogy a bérlő ,feltölti” a talajt a bérleti idő végére a kezdeti állapothoz képest, s ez esetben növeli a föld értékét. Ekkor a tulajdonosnak kártalanítani kell a bérlőt, kompenzálandó a számára visszamaradó bérlői többletráfordításokat. Ugyanez a helyzet akkor is, ha a bérlő értéknövelő beruházást hajtott végre a földön - pl. bekerítette -, mely visszamaradva a tulajdonos számára, növeli az ingatlan értékét.)

E munka elején utaltunk már arra, hogy a bizalmatlanság, a kérdések elől való elzárkózás nagyban nehezítette munkánkat. Sajnos ugyanezt kell megismételnünk most, amikor arról szólunk, hogy a felmérés végén kértük a gazdálkodó szervezeteket, hogy juttassanak el hozzánk egy bérleti szerződés mintát, hogy konkrétan tanulmányozhassuk azok vonásait, tartalmi elemeit. A 22 földet bérlö gazdaságból sajnos csak 14 (64\%) juttatta el hozzánk 
bérleti szerződését, noha természetesen nem kitöltött szerződést kértünk. Mivel ezek a szerződések is igen heterogének, ezért összevetésükre, további vizsgálatukra nem vállalkozunk, így a szerződések tartalmára vonatkozóan az eddigieken túl, több vizsgálatot nem végzünk.

\section{ÖSSZEGZÉS}

A kutatás összegzéseként megállapítható, hogy a földtulajdonlás - használat vonatkozásában 2000-re a kárpótlás utáni állapothoz képest nem sok változás történt. A tulajdonlás zömmel most is azokhoz kapcsolódik, akik nem akarják használni tulajdonukat, ezért a földhasználat általános jogcíme - az esetleges saját tulajdonú földet kiegészítendő ma is a bérlet. A földbérlő gazdaságok nagyon eltérő viszonyok között gazdálkodnak, bár törekednek arra, hogy inkább a jobb minőségü földeket vegyék bérbe. A vizsgált gazdaságok zömmel növelnék a rendelkezésükre álló földterületet, vásárlás illetve bérlet útján. A vásárlást a még mindig várható további árnövekedés miatt jó befektetésként értékelik, azonban tőkehiány miatt föleg a bérlet jöhet szóba területnövelési módként. A földet bérlő gazdaságok nagyon sok tulajdonossal állnak kapcsolatban, s az általuk használt termőföld igen elaprózódott, nagyon sok tagban található. A szerződések nagy része írásos megállapodás, azonban még mindig magas a szóbeli szerződések aránya, melyek leszorítása célként fogalmazható meg.
Jellemző a középtávú bérleti szerződések dominanciája, ami mindkét fél érdekének megfelel, ugyanakkor még mindig magas a rövid távra szóló megállapodások részaránya is. A bérleti díj átlagos alakulása a vizsgált gazdaságok vonatkozásában kiegyensúlyozottnak tekinthető, $16000 \mathrm{Ft} /$ ha körüli értéken alakul. Többnyire a bérlök azonos bérleti díjat fizetnek a tulajdonosoknak, azonban bizonyos esetekben előfordul a differenciálás. A szerződések többségében fix összegü bérleti díjat fizet a bérlö, e mellett előfordul, hogy a bérleti díjat a termés, illetve az értékesítési ár változásától teszik függővé a felek. A bérleti díj átlagosan 16\%-át teszi ki a termelés költségeinek a vizsgált gazdaságokban, akik a bérbe veendő földek kiválasztásakor zömmel igyekeztek a földminőséget és a területnagyságot figyelembe venni. Néhány esetben a jobb minőségü föld egységéért nagyobb díjat hajlandók fizetni a gazdaságok, de ez nem általános tendencia, inkább igaz az, hogy egyforma a jobb és a rosszabb minőségü földek egységére fizetett fajlagos bérleti díj alakulása. A földtulajdonosok igazából nem szólhatnak bele földjük használatába a bérleti idő alatt, és összességében jellemző a szerződésekre az, hogy lényeges kérdéseket nem, vagy nem eléggé körültekintően szabályoznak, így a szerződések fejlesztése szükséges a jövőben. Az elkövetkezendő 2 évben a kutatást megismételve, 2001-re és 2002-re vonatkozóan tovább vizsgáljuk a földtulajdonlás és használat alakulását, figyelemmel kísérve a változásokat.

\section{IRODALOM}

Pálovics B-né (1997): Földbirtok - politika az Európai Unióban. A földkérdésről: Info - Társadalomtudomány, 41. MTA, Budapest, 7-14.

Pfau E. (1995): Különböző méretű vállalkozások eszközszükséglete és kihasználásuk összefüggései. A Debreceni Agrártudományi Egyetem a Tiszántúl mezőgazdaságáért, Hódmezővásárhely, I. kötet, 47-48.

Posta L. (1997): Tulajdonosi és vállalkozói érdekek a fölhasználatban. Kandidátusi értekezés, DATE, Debrecen, 88119
Szabó G. (1997): Földjogi viszonyok az Amerikai Egyesült Államokban és Kanadában. A földkérdésről: Info Társadalomtudomány, 41. MTA, Budapest, 29-34.

Szücs I. (1998): A föld ára és bére. Agroinform Kiadó, Budapest, $156-186$.

Tanka E. (1997): A magyar földtulajdoni és földhasználati viszonyok alakulása. A földkérdésről: Info Társadalomtudomány, 41. MTA, Budapest, 15-22.

1994. évi LV. tv. a termőföldről. Magyar Közlöny, 69. 2533-2546. 